$$
\text { "tmcs-kiss" — 2013/5/24 — 16:31 — page } 21 \text { — \#1 }
$$

\title{
Comparing the IT skills and the programming knowledge of Hungarian students specialized in informatics with Romanian students attending a science course or a mathematics-informatics course
}

\section{GÁBOR KISS}

Abstract. The goal of this research is an analysis of the IT skills and programming knowledge of Hungarian and Romanian students attending a Science course or a MathematicsInformatics course. Analysed was how effectively can students from different grades answer questions dealing with different subjects. After having evaluated the test results correctness of the original presumption emerged. Significance level was $5 \%$ through the analysis. Significant divergency in knowledge of Hungarian students and Romanian students of Humanities (Profil Uman) was found in $11^{\text {th }}$ and $12^{\text {th }}$ grades too. Romanian students attending a science course (Profil Real) and a Mathematics-Informatics course scored higher in programming than their Hungarian counterparts specialized in Informatics in the $11^{\text {th }}$ grade. After the evaluation a final conclusion can be made: Romanian students of the Real Profile have the same or more practice in programming than Hungarian students specialized in Informatics, though the latters have the same or better IT skills. Unfortunately, Hungarian teachers concentrate on word processing and spreadsheet calculation and teach programming just for the students specialized in Informatics, although algorithm thinking would be important for every student before finishing secondary school.

Key words and phrases: measuring, information technology, knowledge, level, hungarian, romanian, students.

ZDM Subject Classification: Q23, Q24, Q63, Q64, Q73, Q74.

\section{Introduction}

Some research was done comparing the Schoolsystems [1] and the role of Information and Communication Technology in the education of some European countries [2], [3], [4]. The goal of this research is an analysis of the IT skills 
and programming knowledge of Hungarian and Romanian students attending a Science course or a Mathematics-Informatics course. The National Basic Curriculum of Hungary describes the curriculum grade by grade, subject by subject to teachers.

Information Technology education in Romania bears a close resemblance to the one in Hungary from the point of view of the material discussed. Theoretical knowledge, word processing, spreadsheet calculation, database management and programming are parts of the curriculum in both countries.

Though topics are the same but the number of CS classes are different. This research is analysing whether differences in the IT skills of students depend on the number classes they are taught in or not.

In order to be able to compare the students' IT skills in the different countries a detailed analysis was needed. Various curriculums in the different grades had to be checked, as well as the number of weekly Informatics classes and whether Informatics was a compulsory or an optional subject. Still, this is not enough to carry out the examination. Further, the students' knowledge had to be checked in various grades of the different countries. To be able to make comparisons between these students, a uniform questionnaire had to be devised in which questions regarding the different subject matters of Information Technology had to be asked. Only after having sent out these questionnaires to students of the different countries could the survey be carried out on the basis of their answers.

First, let us have a look at how many Informatics classes are held in the respective countries (Table 1.). Information Technology is only an elective course in the last two years of the secondary school in Hungary.

Table 1. Number of Information Technology classes in different grades

\begin{tabular}{|c|c|c|c|c|c|c|c|c|c|c|c|c|}
\hline Country & 1. & 2. & 3. & 4. & 5. & 6. & 7. & 8. & 9. & 10. & 11. & 12. \\
\hline Hungary & 1 & 1 & 1 & 1 & 2 & 2 & 2 & 2 & 2 & 2 & $3^{1}$ & $3^{1}$ \\
\hline Roma & 0 & 0 & 0 & 0 & $0 / 1$ & $0 / 1$ & $0 / 1$ & $0 / 1$ & $\begin{array}{l}1-2 \\
3-4 \\
6-7^{2}\end{array}$ & $\begin{array}{l}1-2 \\
3-4 \\
6-7^{2}\end{array}$ & $\begin{array}{l}1-2 \\
3-4 \\
6-7^{2}\end{array}$ & $\begin{array}{l}1-2 \\
3-4 \\
6-7^{2}\end{array}$ \\
\hline
\end{tabular}

In Romanian schools the bulk of students get their first experience in Information Technology in the $9^{\text {th }}$ grade. It also happens that students study Informatics in one class a week for one or two years in the $5^{\text {th }}-8^{\text {th }}$ grades of certain schools, but this is rare and the curriculum also depends on the teacher to a great extent.

\footnotetext{
${ }^{1}$ selectable
}

${ }^{2}$ depends on specialization 
In Hungary students start to learn Information Technology earlier, so my starting hypothesis' were based on this knowledge before making a comparison.

The first starting hypothesis was that Hungarian students specialized in Informatics have better IT skills and programming knowledge than Romanian counterparts attending a science course.

The second starting hypothesis was that Hungarian students specialized in Informatics have the same IT skills and programming knowledge as Romanian students specialized in Mathematics-Informatics because they spend more time on this subject.

\section{Information Technology education in Hungary}

IT education is based on a national curriculum in Hungary [5]. According to the National Basic Curriculum (NBC) of Hungary the use of IT is to be demonstrated in the first four school grades since 2003 (e.g. search on the Internet, painting with computers etc.) and is taught in 1 class weekly. According to the Information Technology curriculum the following subjects are taught from the $5^{\text {th }}$ grade to the $12^{\text {th }}$ grade at the schools of Hungary in 2 classes weekly:

- Word processing

- Spreadsheet calculation

- Presentation

- Algorithm and programming

- Database management

Table 2. The subjects of CS by grades in Hungary

\begin{tabular}{|l|c|c|c|c|c|c|c|c|}
\hline \multicolumn{1}{|c|}{ Subject } & \multicolumn{7}{|c|}{ Grade } \\
\hline & 5 & 6 & 7 & 8 & 9 & 10 & 11 & 12 \\
\hline Word processing & & $\sqrt{ }$ & $\sqrt{ }$ & $\sqrt{ }$ & $\sqrt{ }$ & & & \\
\hline Spreadsheet calculation & & & & $\sqrt{ }$ & $\sqrt{ }$ & & & \\
\hline Presentation & & & & & & $\sqrt{ }$ & & \\
\hline Algorithm and programming & & & $\sqrt{ }$ & $\sqrt{ }$ & $\sqrt{ }$ & & & \\
\hline Database management & & & & & $\sqrt{ }$ & & & \\
\hline
\end{tabular}

Generally the Microsoft Office packet is taught and it can be seen that teaching Word processing takes 4 years in Hungary (Table 2.). Basic algorithms or rather programming appears in Information Technology sooner, but recursion, 


$$
\text { "tmcs-kiss" — 2013/5/24 — 16:31 — page } 24 \text { — \#4 }
$$

list and tree data structures are only selectable part of the curriculum. Database management begins in the $9^{\text {th }}$ grade. In grades $11-12$ CS is just selectable. At basic level it is taught 2 hours weekly, on a higher level 3 hours weekly and a final exam can be taken.

\section{Information Technology education in Romania}

The Romanian school system differs from the Hungarian one since the students take a country-wide ability test at the end of the $8^{\text {th }}$ grade [6]. Admittance into the secondary school they have opted is based on their scores. Those who would like enroll into a Mathematics-Informatics course of the chosen secondary school have to score higher in this country-wide test. In Romanian schools the bulk of the students have their first experience in Information Technology in the $9^{\text {th }}$ grade. It also happens that students study Informatics in one class a week for one or two years in the $5^{\text {th }}-8^{\text {th }}$ grades in certain schools, but this is rare and the curriculum depends heavily on the teacher.

Syllabuses usually involve simply the use of Office tools. Algorithms and database management are not taught. It is a nation-wide phenomenon that Information Technology is taught from the $9^{\text {th }}$ grade in Romania but the curriculum prescribes the subject matters covered and also determines the weekly number of Informatics classes.

If admitted to a social science course, there are one or two Informatics classes a week in the first two years of secondary school education. Students in the $9^{\text {th }}$ grade are taught managing the operating system, word processing, e-mailing, using the Internet and preparing a simple homepage. Students in the $10^{\text {th }}$ grade learn preparing presentations, spreadsheet calculation and database management so programming is still not mentioned.

Those who are admitted to a natural sciences course are taught Information Technology in 3-4 classes a week in secondary school; this number can be raised to 6-7 classes a week if you study in a Mathematics-Informatics course and have chosen to learn Informatics intensively.

Students admitted to a natural sciences course learn word processing, spreadsheet calculation and preparing presentations at a similar pace as students of social sciences courses but the higher weekly number of classes allows to deal with some other topics as well. The main task is to get to know the basic algorithms and the use of one-dimensional arrays in the $9^{\text {th }}$ grade. To find and arrange various algorithms are parts of the curriculum in the $10^{\text {th }}$ grade. Students in the $11^{\text {th }}$ 


$$
\text { "tmcs-kiss" — 2013/5/24 — 16:31 — page } 25 \text { — \#5 }
$$

grade get acquainted with two-dimensional arrays, functions, procedures, stacks, lists, row data structures, binary trees and backtracking algorithms. In the $12^{\text {th }}$ grade the focus is put on database management: preparation of databases, tables, relations, reports, queries and forms [7].

\section{Comparison tools}

It is possible to compare the Hungarian and Romanian Information Technology education examining the students' knowledge. Since it is quite difficult to send out questionnaires physically to the various schools and the order of the questions can not be changed in that case, and also because students sitting close to each other in the classroom can see the other's answers, so the most effective solution seemed to be a web-based Informatics test.

Some research was done making test to standardize the IT education in Switzerland [8] and Austria [9].

Questions of various difficulties were formed in the main topics of Information Technology. The topics chosen were part of Informatics education in almost every country: theoretical knowledge, word processing, spreadsheet calculation, database management and programming. There can be significant deviations in the curricula of some countries; therefore the test was expanded with questions on cryptographical knowledge as well as formal languages and automats since in certain German provinces these are also part of the Information Technology curriculum (note: the test is appropriate to compare the IT education of other countries too.) [10].

The database structure for the test had to be planned in a suitable way so that the data could be obtained later on. The personal data of the students filling in the test were put in a separate table as well as their answers to the questions.

When filling in the test the students first had to give their actual grade and some other data (Figure 1.). If students gave the username of their teacher then the teacher also could see how they succeeded and would get a feedback on their progress. Grade was important because he/she would get a question sheet depending on the grade given.

Students could mark topics not taught to them (except basic information technology and office packages). If they marked one, the system would not ask questions dealing with the topic but saved it with the answer "I have never learned that". With this option students got fewer questions and answers would flow in at a quicker pace. Next, students could begin to fill in the test. 


$$
\text { "tmcs-kiss" — 2013/5/24 — 16:31 — page } 26 \text { — \#6 }
$$

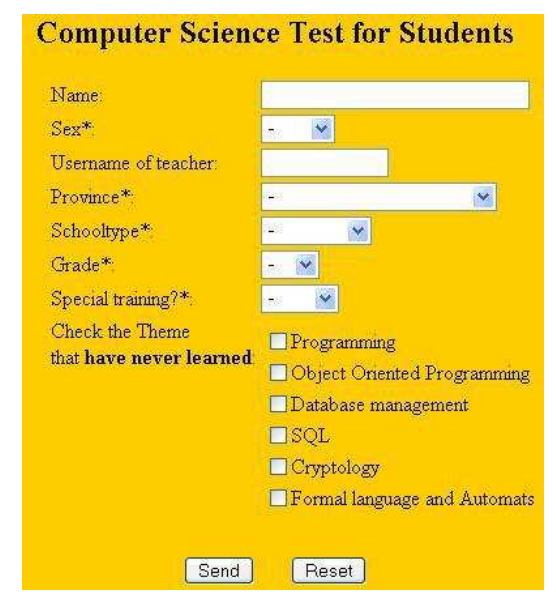

Figure 1. Student's registration entries

Every test question has 6 possible answers, only one of which is correct, 3 of them bad, and the $5^{\text {th }}$ choice is: "I have never learned that", the $6^{\text {th: }}$ "I have forgotten it". The answers "I have never learned that" and "I have forgotten it" show which part of the curriculum the students have not learned in that grade and if they could remember it or not. Every question has two time limits given in seconds. The first is the minimum time to read, understand and answer the question, the second is the maximum answering time. The software saves the total time used by the student. These time limits are not seen or known by the students. These are used during the evaluation so a correct answer is accepted only if it arrives in the available time interval.

Teachers can register on this site too if they are willing to give some of their data. The system is protected by registration code, and registered teachers can $\log$ in with their username and password. If a student filling in the test gives the username of the teacher too than the teacher can later see his/her answers and the results.

Some reports can be generated helping the work of the teacher. It is recorded whether the students have given them the right to inspect. It is also indicated if they have marked a question as not learned or if the topic of the question is familiar to them but they have forgotten the right answer.

The evaluation of the answers is only possible after processing the saved data. The first step is to check whether the students of the given country have learned 
the given topic. If they have not, the comparison with the data of the students of other countries is impossible to make.

If the students knew the topic because they had learned it, it had to be checked if the time spent answering the questions was within the limits given. If so, the answer could be accepted as right.

The mean and the standard deviation of the right answers had to be calculated in the various grades and countries and make comparisons with the help of statistical means. In order to be able to do this, enough students filling in the test were needed in each grade. When comparing the IT skills of students in two countries, the Independent Samples T-test was taken.

\section{Number of participiants}

The knowledge of the Hungarian students specialized in Information Technology and that of the Romanian students attending a science course and a Mathematics- Informatics course are worth comparing only in the last two years of secondary school because the number of students filling in the test reaches the required amount there (Table 3 .).

Table 3. The number of participants per grades and countries

\begin{tabular}{|c|c|c|c|}
\hline \multirow[b]{2}{*}{ Grades } & Hungarian & \multicolumn{2}{|r|}{ Romanian } \\
\hline & $\begin{array}{l}\text { Informatics } \\
\text { course }\end{array}$ & $\begin{array}{l}\text { sciences } \\
\text { course }\end{array}$ & $\begin{array}{c}\text { Mathematics-Informatics } \\
\text { course }\end{array}$ \\
\hline 5 & 0 & 0 & 0 \\
\hline 6 & 0 & 0 & 0 \\
\hline 7 & 0 & 0 & 0 \\
\hline 8 & 0 & 0 & 0 \\
\hline 9 & 0 & 0 & 0 \\
\hline 10 & 0 & 0 & 0 \\
\hline 11 & 69 & 94 & 212 \\
\hline 12 & 91 & 87 & 158 \\
\hline
\end{tabular}

After the examination it turns out what knowledge the students can acquire in the intensive Informatics training in the different countries and it is also revealed that the students of which country know more of the various topics. 


$$
\text { "tmcs-kiss" — 2013/5/24 — 16:31 — page } 28 \text { - \#8 }
$$

\section{Comparing the informatics knowledge of Hungarian and Romanian students - survey results}

The web-test on Informatics was filled in by altogether 1002 students from 22 Romanian cities. The comparison between the Hungarian students receiving basic Information Technology education and the Romanian students attending a social science course can only be made in the $10^{\text {th }}$ and $12^{\text {th }}$ grades.

The survey could not be carried out up to the $8^{\text {th }}$ grade since teaching Informatics is only compulsory from the $9^{\text {th }}$ grade in Romania; students do not learn Informatics in a uniform system and it depends on the teacher what is taught.

In Hungary, students can learn more Informatics weekly in the last two years of secondary school if they choose it as an optional subject.

In Romania students learn more Information Technology if they are specialized in natural science, and if attending a Mathematics-Informatics course then they have even more classes a week. So the comparison should be limited to the students learning Informatics in the last two years of secondary school.

6.1. Survey results of the Hungarian students specialized in Informatics and the Romanian students attending a science course in the second part of secondary school on the basis of topics

\subsubsection{Result by subjects}

The following table shows the results by countries and by subject (Table 4.). The mean shows how many questions could the students answer, the next column the ratio in percentage, and the last one the standard deviations.

Looking at the data in the table you can see that Hungarian students achieve better results in the field of theoretical knowledge, word processing, spreadsheet calculation, database management and programming in the $11^{\text {th }}$ grade. They learn some SQL while the Romanian students do not. We have previously noticed that Hungarian students did not learn programming in the basic Information Technology education. They could answer right just $27 \%$ of the questions as a result of the first year spent in a specialized Informatics class. Object-oriented programming is missing form the education in both countries.

In the $12^{\text {th }}$ grade the Hungarian students were still ahead in theoretical knowledge, word processing and spreadsheet calculation but Romanian students caught up in the field of database management. This is the grade where Romanian students get acquainted with this topic. Based on their scores you can say they 
learn more of SQL and show more proficiency in programming; the Hungarian students do not perform better any more. There is one essential difference between the educational programs of the two countries: Romanian students attending a science course learn the basics of object-oriented programming in the last year of secondary school while their Hungarian peers do not, not even in specialized Informatics classes.

Table 4. The mean and the standard deviation of right answers by Hungarian students specialized in informatics and Romanian students attending a science course in the second part of secondary school on the basis of topics

\begin{tabular}{|c|c|c|c|c|c|}
\hline Grade & Subject & $\begin{array}{l}\text { Nationality } \\
\text { of students }\end{array}$ & Mean & $\begin{array}{l}\text { Percent of the } \\
\text { correct answers }\end{array}$ & $\begin{array}{c}\text { Std. } \\
\text { Deviation }\end{array}$ \\
\hline \multirow[t]{2}{*}{11} & \multirow{2}{*}{$\begin{array}{l}\text { Theoretical } \\
\text { knowledge }\end{array}$} & Hungarian & 13,43 & $29,21 \%$ & 7,61 \\
\hline & & Romanian & 8,33 & $18,12 \%$ & 3,26 \\
\hline \multirow[t]{2}{*}{11} & \multirow{2}{*}{$\begin{array}{l}\text { Word } \\
\text { processing }\end{array}$} & Hungarian & 5,48 & $39,13 \%$ & 3,30 \\
\hline & & Romanian & 3,00 & $21,43 \%$ & 2,04 \\
\hline \multirow[t]{2}{*}{11} & \multirow{2}{*}{$\begin{array}{l}\text { Spreadsheet } \\
\text { calculation }\end{array}$} & Hungarian & 3,85 & $20,24 \%$ & 1,97 \\
\hline & & Romanian & 2,50 & $13,16 \%$ & 1,57 \\
\hline \multirow[t]{2}{*}{11} & \multirow{2}{*}{$\begin{array}{l}\text { Database } \\
\text { management }\end{array}$} & Hungarian & 3,09 & $17,15 \%$ & 2,67 \\
\hline & & Romanian & 1,42 & $7,87 \%$ & 1,38 \\
\hline \multirow[t]{2}{*}{11} & \multirow[t]{2}{*}{ SQL } & Hungarian & 0,45 & $5,62 \%$ & 1,55 \\
\hline & & Romanian & 0,00 & $0,00 \%$ & 0,00 \\
\hline \multirow[t]{2}{*}{11} & \multirow[t]{2}{*}{ Programming } & Hungarian & 7,09 & $27,26 \%$ & 4,67 \\
\hline & & Romanian & 5,42 & $20,83 \%$ & 1,68 \\
\hline \multirow[t]{2}{*}{11} & \multirow[t]{2}{*}{$\mathrm{OOP}$} & Hungarian & 0,16 & $1,99 \%$ & 0,66 \\
\hline & & Romanian & 0,00 & $0,00 \%$ & 0,00 \\
\hline \multirow[t]{2}{*}{12} & \multirow{2}{*}{$\begin{array}{l}\text { Theoretical } \\
\text { knowledge }\end{array}$} & Hungarian & 16,81 & $36,55 \%$ & 6,86 \\
\hline & & Romanian & 11,64 & $25,30 \%$ & 5,14 \\
\hline \multirow[t]{2}{*}{12} & \multirow{2}{*}{$\begin{array}{l}\text { Word } \\
\text { processing }\end{array}$} & Hungarian & 5,75 & $41,05 \%$ & 2,35 \\
\hline & & Romanian & 4,27 & $30,52 \%$ & 2,00 \\
\hline \multirow[t]{2}{*}{12} & \multirow{2}{*}{$\begin{array}{l}\text { Spreadsheet } \\
\text { calculation }\end{array}$} & Hungarian & 4,59 & $24,18 \%$ & 3,53 \\
\hline & & Romanian & 2,91 & $15,31 \%$ & 2,12 \\
\hline \multirow[t]{2}{*}{12} & \multirow{2}{*}{$\begin{array}{l}\text { Database } \\
\text { management }\end{array}$} & Hungarian & 2,68 & $14,90 \%$ & 2,92 \\
\hline & & Romanian & 4,09 & $22,73 \%$ & 2,07 \\
\hline \multirow[t]{2}{*}{12} & \multirow[t]{2}{*}{ SQL } & Hungarian & 1,22 & $15,25 \%$ & 2,32 \\
\hline & & Romanian & 3,00 & $37,50 \%$ & 2,65 \\
\hline \multirow[t]{2}{*}{12} & \multirow[t]{2}{*}{ Programming } & Hungarian & 5,60 & $21,56 \%$ & 3,96 \\
\hline & & Romanian & 6,36 & $24,48 \%$ & 1,50 \\
\hline \multirow[t]{2}{*}{12} & \multirow[t]{2}{*}{$\mathrm{OOP}$} & Hungarian & 0,23 & $2,88 \%$ & 0,70 \\
\hline & & Romanian & 1,64 & $20,45 \%$ & 1,57 \\
\hline
\end{tabular}




$$
\text { "tmcs-kiss" — 2013/5/24 — 16:31 — page } 30 \text { — \#10 }
$$

\subsubsection{Analysis of the means by subjects}

The next step in the analysis was to inspect whether the means by subject would differ if using the Independent samples test. The null hypothesis was that no significant difference would exist between the means of all subjects by countries. Because of having two independent samples it was possible to use the T-test to decide whether the hypothesis was true or not (Table 5.). If the analysis of the results (Levene test) showed the variance of the two groups different $(p<0,05)$ [11], in this case the means could be compared with Welch's $t$ test $(p<0,05)$ [12], else the means could be compared with T-test $(p<0,05)$ [13].

Table 5. Independent sample test of Hungarian students specialized in informatics and Romanian students attending a science course in the second part of secondary school on the basis of topics

\begin{tabular}{|c|l|c|c|c|c|c|}
\hline \multirow{2}{*}{ Grade } & \multirow{2}{*}{ Subject } & \multicolumn{2}{|c|}{$\begin{array}{c}\text { Levene's test } \\
\text { for Equality } \\
\text { of variances }\end{array}$} & \multicolumn{2}{c|}{$\begin{array}{c}\text { T-test for } \\
\text { equality } \\
\text { of means }\end{array}$} & \multirow{2}{*}{$\begin{array}{c}\text { means } \\
\text { are } \\
\text { different }\end{array}$} \\
\cline { 3 - 6 } & & F & Sig. & t & $\begin{array}{c}\text { Sig. } \\
\text { (2-tailed) }\end{array}$ & \\
\hline 11 & Theoretical knowledge & 3,89 & 0,05 & 2,28 & 0,03 & yes \\
\hline 11 & Word processing & 3,33 & 0,07 & 2,51 & 0,01 & yes \\
\hline 11 & Spreadsheet calculation & 0,04 & 0,84 & 2,08 & 0,05 & yes \\
\hline 11 & Database management & 8,29 & 0,01 & 2,11 & 0,00 & yes \\
\hline 11 & SQL & 4,26 & 0,04 & 1,00 & 0,02 & yes \\
\hline 11 & Programming & 7,74 & 0,01 & 1,22 & 0,03 & yes \\
\hline 11 & OOP & 3,04 & 0,08 & 0,84 & 0,40 & no \\
\hline 12 & Theoretical knowledge & 0,63 & 0,43 & 2,42 & 0,02 & yes \\
\hline 12 & Word processing & 0,23 & 0,63 & 1,99 & 0,05 & yes \\
\hline 12 & Spreadsheet calculation & 4,08 & 0,04 & 1,57 & 0,03 & yes \\
\hline 12 & Database management & 1,00 & 0,32 & $-1,55$ & 0,12 & no \\
\hline 12 & SQL & 1,01 & 0,32 & $-2,37$ & 0,02 & yes \\
\hline 12 & Programming & 5,45 & 0,02 & $-0,63$ & 0,23 & no \\
\hline 12 & OOP & 18,58 & 0,00 & $-5,31$ & 0,01 & yes \\
\hline
\end{tabular}

Having finished the statistical analysis you can see there are no differences in object-oriented programming between Hungarian and Romanian students in the $11^{\text {th }}$ grade; they do not learn this topic at all. Hungarian students have better IT skills and programming knowledge in this grade.

In the $12^{\text {th }}$ grade the Hungarian students do not obtain higher scores in database management and programming anymore; there are no differences between 


$$
\text { "tmcs-kiss" — 2013/5/24 — 16:31 — page } 31 \text { — \#11 }
$$

the means of correct answers, the Romanian students caught up with their Hungarian counterparts, but there are significant differences between the means of good answers concerning the other fields of Information Technology. That means Hungarian students have better IT skills but not deeper programming knowledge in this grade.

6.2. Survey results of the Hungarian students specialized in Informatics and the Romanian students attending a Mathematics-Informatics course in the second part of secondary school on the basis of topics

\subsubsection{Result by subjects}

The following table shows the results by countries and by subject (Table 6.). The mean shows how many questions could the students answer, the next column shows the ratio in percentage and the last one the standard deviations.

In the $11^{\text {th }}$ grade Hungarian students attending an Informatics course performed better in theoretical knowledge, word processing, spreadsheet calculation, database management and programming than Romanian students attending a science course. On the basis of the data in the table this advantage remains only in the field of word processing if compared with the scores of the Romanian students attending a Mathematics-Informatics course; word processing is noticeably more emphasized in Hungary. The topic of SQL is only mentioned in both countries. Romanian students had higher scores in programming. They have not learned object-oriented programming in this grade yet.

In the $12^{\text {th }}$ grade the Hungarian advantage in the field of word processing disappears, Romanian students achieved the same scores. They even produced better results in the field of database management, SQL and programming than their Hungarian peers and their results are similar to those of the students attending a science course since object-oriented programming appears in this grade.

\subsubsection{Analysis of the means by subjects}

The next step in the analysis was to inspect whether the means by subject would differ if using the Independent samples test (Table 7.).

Looking at the table containing the statistical data you can see that the analysis carried out on the basis of percentile data has proved to be correct.

In the $11^{\text {th }}$ grade Romanian students achieved better results in programming, while their Hungarian peers were better in word processing but they have the same knowledge in the other fields. 
Table 6. The mean and the standard deviation of right answers by Hungarian students specialized in informatics and Romanian students attending a mathematics-informatics course in the second part of secondary school on the basis of topics

\begin{tabular}{|c|c|c|c|c|c|}
\hline Grade & Subject & $\begin{array}{c}\text { Nationality } \\
\text { of studentsn }\end{array}$ & Mean & $\begin{array}{l}\text { Percent of the } \\
\text { correct answers }\end{array}$ & $\begin{array}{c}\text { Std. } \\
\text { Deviation }\end{array}$ \\
\hline \multirow[t]{2}{*}{11} & \multirow{2}{*}{$\begin{array}{l}\text { Theoretical } \\
\text { knowledge }\end{array}$} & Hungarian & 13,43 & $29,21 \%$ & 7,61 \\
\hline & & Romanian & 12,41 & $26,97 \%$ & 4,01 \\
\hline \multirow[t]{2}{*}{11} & \multirow{2}{*}{$\begin{array}{l}\text { Word } \\
\text { processing }\end{array}$} & Hungarian & 5,48 & $39,13 \%$ & 3,30 \\
\hline & & Romanian & 3,85 & $27,51 \%$ & 2,20 \\
\hline \multirow[t]{2}{*}{11} & \multirow{2}{*}{$\begin{array}{l}\text { Spreadsheet } \\
\text { calculation }\end{array}$} & Hungarian & 3,85 & $20,24 \%$ & 1,97 \\
\hline & & Romanian & 3,41 & $17,93 \%$ & 2,15 \\
\hline \multirow[t]{2}{*}{11} & \multirow{2}{*}{$\begin{array}{l}\text { Database } \\
\text { management }\end{array}$} & Hungarian & 3,09 & $17,15 \%$ & 2,67 \\
\hline & & Romanian & 3,26 & $18,11 \%$ & 2,60 \\
\hline \multirow[t]{2}{*}{11} & \multirow[t]{2}{*}{$\overline{\mathrm{SQL}}$} & Hungarian & 0,45 & $5,62 \%$ & 1,55 \\
\hline & & Romanian & 0,59 & $7,41 \%$ & 1,28 \\
\hline \multirow[t]{2}{*}{11} & \multirow{2}{*}{ Programming } & Hungarian & 7,09 & $27,26 \%$ & 4,67 \\
\hline & & Romanian & 10,70 & $41,17 \%$ & 2,66 \\
\hline \multirow[t]{2}{*}{11} & \multirow[t]{2}{*}{$\mathrm{OOP}$} & Hungarian & 0,16 & $1,99 \%$ & 0,66 \\
\hline & & Romanian & 0,00 & $0,00 \%$ & 0,00 \\
\hline \multirow[t]{2}{*}{12} & \multirow{2}{*}{$\begin{array}{l}\text { Theoretical } \\
\text { knowledge }\end{array}$} & Hungarian & 16,81 & $36,55 \%$ & 6,86 \\
\hline & & Romanian & 15,30 & $33,26 \%$ & 4,92 \\
\hline \multirow[t]{2}{*}{12} & \multirow{2}{*}{$\begin{array}{l}\text { Word } \\
\text { processing }\end{array}$} & Hungarian & 5,75 & $41,05 \%$ & 2,35 \\
\hline & & Romanian & 5,70 & $40,71 \%$ & 2,27 \\
\hline \multirow[t]{2}{*}{12} & \multirow{2}{*}{$\begin{array}{l}\text { Spreadsheet } \\
\text { calculation }\end{array}$} & Hungarian & 4,59 & $24,18 \%$ & 3,53 \\
\hline & & Romanian & 5,20 & $27,37 \%$ & 2,63 \\
\hline \multirow[t]{2}{*}{12} & \multirow{2}{*}{$\begin{array}{l}\text { Database } \\
\text { management }\end{array}$} & Hungarian & 2,68 & $14,90 \%$ & 2,92 \\
\hline & & Romanian & 5,75 & $31,94 \%$ & 3,11 \\
\hline \multirow[t]{2}{*}{12} & \multirow[t]{2}{*}{$\overline{\mathrm{SQL}}$} & Hungarian & 1,22 & $15,25 \%$ & 2,32 \\
\hline & & Romanian & 4,05 & $50.63 \%$ & 3,33 \\
\hline \multirow[t]{2}{*}{12} & \multirow[t]{2}{*}{ Programming } & Hungarian & 5,60 & $21,56 \%$ & 3,96 \\
\hline & & Romanian & 13,05 & $50,19 \%$ & 2,98 \\
\hline \multirow[t]{2}{*}{12} & \multirow[t]{2}{*}{$\mathrm{OOP}$} & Hungarian & 0,23 & $2,88 \%$ & 0,70 \\
\hline & & Romanian & 1,05 & $13,13 \%$ & 1,54 \\
\hline
\end{tabular}

In the $12^{\text {th }}$ grade the Romanian students caught up with the Hungarians in the field of word processing and achieved better results in programming (at OOP too), database management and SQL. Romanian students attending a Mathematics-Informatics course students have the same IT skills and better programing knowledge at the end of the secondary grammar school than Hungarians specialized in Informatics. 
Table \%. Independent sample test of Hungarian students specialized in informatics and Romanian students attending a mathematicsinformatics course in the second part of secondary school on the basis of topics

\begin{tabular}{|c|l|c|c|c|c|c|}
\hline \multirow{2}{*}{ Grade } & \multirow{2}{*}{ Subject } & \multicolumn{2}{|c|}{$\begin{array}{c}\text { Levene's test } \\
\text { for Equality } \\
\text { of variances }\end{array}$} & \multicolumn{2}{c|}{$\begin{array}{c}\text { T-test for } \\
\text { equality } \\
\text { of means }\end{array}$} & \multirow{2}{*}{$\begin{array}{c}\text { means } \\
\text { are } \\
\text { different }\end{array}$} \\
\cline { 3 - 6 } & & F & Sig. & t & $\begin{array}{c}\text { Sig. } \\
\text { (2-tailed) }\end{array}$ & \\
\hline 11 & Theoretical knowledge & 4,99 & 0,03 & 0,67 & 0,39 & no \\
\hline 11 & Word processing & 3,20 & 0,08 & 2,36 & 0,02 & yes \\
\hline 11 & Spreadsheet calculation & 0,93 & 0,34 & 0,77 & 0,44 & no \\
\hline 11 & Database management & 0,01 & 0,91 & $-0,29$ & 0,77 & no \\
\hline 11 & SQL & 0,21 & 0,65 & $-0,43$ & 0,67 & no \\
\hline 11 & Programming & 6,30 & 0,01 & $-3,79$ & 0,00 & yes \\
\hline 12 & Theoretical knowledge & 1,58 & 0,21 & 0,93 & 0,26 & no \\
\hline 12 & Word processing & 0,05 & 0,82 & 0,08 & 0,93 & no \\
\hline 12 & Spreadsheet calculation & 2,86 & 0,09 & $-0,75$ & 0,45 & no \\
\hline 12 & Database management & 0,45 & 0,50 & $-4,20$ & 0,00 & yes \\
\hline 12 & SQL & 10,76 & 0,00 & $-4,53$ & 0,00 & yes \\
\hline 12 & Programming & 0,67 & 0,42 & $-7,92$ & 0,00 & yes \\
\hline 12 & OOP & 31,42 & 0,00 & $-3,67$ & 0,03 & yes \\
\hline
\end{tabular}

Next, a deeper analysis of the different topics of programming follows.

Comparing the Programming knowledge of Hungarian students specialized in Informatics with Romanian students attending a science course in the second part of secondary school

Hungarian students do not learn programming in a basic Informatics course [14], [15]. This means only scores of those students can be analyzed who have chosen Informatics as an optional subject and learn Informatics in the last two years of secondary school [16]. Earlier significant differences were found between the means of good answers in programming at the $11^{\text {th }}$ grade (table). A deeper analysis of the different programming topics was needed to make a decision about the second hypothesis as it was in the case when knowledge by genders was discussed in Hungarian grammar schools [17] and higher education [18].

The following table is a break-down by programming topics, showing what percent of students of this grade could answer correctly the questions put to them (Table 8.). 
Once again a Z-test [19] was accomplished in order to know if the means by Programming topics were equal or not.

Table 8. How many percent of students answered successfully the questions - grouping by Hungarian students specialized in informatics and Romanian students attending a science course in the nationality in the $11^{\text {th }}$ grade

\begin{tabular}{|c|c|c|c|c|c|c|}
\hline & \multicolumn{2}{|c|}{ Hungarian } & \multicolumn{2}{|c|}{ Romanian } & \multirow[b]{2}{*}{$\begin{array}{c}\text { Value of } \\
\text { Z-test }\end{array}$} & \multirow[b]{2}{*}{ Decision } \\
\hline Programming topic & $\%$ & $\begin{array}{l}\text { Std. } \\
\text { dev. }\end{array}$ & $\%$ & $\begin{array}{l}\text { Std. } \\
\text { dev. }\end{array}$ & & \\
\hline Flowchart & $35,2 \%$ & 0,48 & $14,3 \%$ & 0,36 & $-1,18$ & $\begin{array}{l}\text { The means } \\
\text { are equal }\end{array}$ \\
\hline Structogram & $22,0 \%$ & 0,42 & $4,8 \%$ & 0,22 & $-0,52$ & $\begin{array}{l}\text { The means } \\
\text { are equal }\end{array}$ \\
\hline FOR cycle & $43,4 \%$ & 0,50 & $35,7 \%$ & 0,48 & $-2,74$ & $\begin{array}{l}\text { The means } \\
\text { are not equal }\end{array}$ \\
\hline Repeat-Until cycle & $19,2 \%$ & 0,40 & $14,3 \%$ & 0,35 & $-1,44$ & $\begin{array}{l}\text { The means } \\
\text { are equal }\end{array}$ \\
\hline Do-While cycle & $26,4 \%$ & 0,44 & $9,5 \%$ & 0,30 & $-0,93$ & $\begin{array}{l}\text { The means } \\
\text { are equal }\end{array}$ \\
\hline Parameter passing & $16,5 \%$ & 0,37 & $28,6 \%$ & 0,46 & $-2,49$ & $\begin{array}{l}\text { The means } \\
\text { are not equal }\end{array}$ \\
\hline Sort algorithm & $14,3 \%$ & 0,37 & $26,2 \%$ & 0,45 & $-2,36$ & $\begin{array}{l}\text { The means } \\
\text { are not equal }\end{array}$ \\
\hline Array management & $9,9 \%$ & 0,30 & $4,8 \%$ & 0,22 & $-0,70$ & $\begin{array}{l}\text { The means } \\
\text { are equal }\end{array}$ \\
\hline Subroutine & $42,9 \%$ & 0,50 & $36,5 \%$ & 0,49 & $-2,67$ & $\begin{array}{l}\text { The means } \\
\text { are not equal }\end{array}$ \\
\hline Stack management & $12,1 \%$ & 0,33 & $23,8 \%$ & 0,44 & $-2,23$ & $\begin{array}{l}\text { The means } \\
\text { are not equal }\end{array}$ \\
\hline binary three knowledge & $6,0 \%$ & 0,24 & $7,1 \%$ & 0,26 & $-1,09$ & $\begin{array}{l}\text { The means } \\
\text { are equal }\end{array}$ \\
\hline list knowledge & $19,2 \%$ & 0,40 & $21,4 \%$ & 0,42 & $-1,96$ & $\begin{array}{l}\text { The means } \\
\text { are equal }\end{array}$ \\
\hline Recursion & $15,0 \%$ & 0,48 & $22,2 \%$ & 0,42 & $-1,98$ & $\begin{array}{l}\text { The means } \\
\text { are not equal }\end{array}$ \\
\hline binary search algorithm & $11,0 \%$ & 0,31 & $19,0 \%$ & 0,40 & $-1,92$ & $\begin{array}{l}\text { The means } \\
\text { are equal }\end{array}$ \\
\hline The Eight Queens Problem & $25,0 \%$ & 0,28 & $14,3 \%$ & 0,36 & $-1,64$ & $\begin{array}{l}\text { The means } \\
\text { are equal }\end{array}$ \\
\hline
\end{tabular}

In the above case the null hypothesis was that no significant difference existed between the means by nationality. The monitoring was held on the $p=5 \%$ significancy level. The critical value of Z-test was between $-1,96$ and 1,96 at $p=5 \%$ significancy level. If the calculated value of $\mathrm{Z}$-test was in this range, 
the null hypothesis could be kept. The next table shows the calculated values of Z-test and the decision on keeping or not the null hypothesis by nationality.

According to the table it can be asserted at $p=5 \%$ significancy level that Hungarian students specialized in Informatics and Romanian students attending a science course are not on the same knowledge level regarding the different programming topics in the $11^{\text {th }}$ grade (Table).

Hungarian students answered the FOR cycle and subroutine questions more successfully, but, on the other hand, Romanian students had the same or even better knowledge in parameter passing, sort algorithm, stack management and recursion.

Romanian students attending a science course in the $11^{\text {th }}$ grade have more practice in Programming than Hungarian ones specialized in Informatics. To offset this disadvantage Hungarian teachers should start to teach programming already in the $7^{\text {th }}$ grade (in accordance with the National Basic Curriculum).

Comparing the Programming knowledge of Hungarian students specialized in Informatics with Romanian students attending a Mathematics-Informatics course in the second part of secondary school

Earlier significant differences were found between the means of good answers regarding programming topics in the $11^{\text {th }}$ grade as well as in the $12^{\text {th }}$ grade (Table 9.). A further analysis is made to see the differences by programming topics.

The following table is a break-down by programming topics, showing what percent of students in the $11^{\text {th }}$ grade could answer correctly the questions put to them.

According to the table it can be said at $p=5 \%$ significancy level that bigger part of Romanian students students attending a Mathematics-Informatics course could give correct answers than Hungarian students specialized in Informatics, except the topics Structogram, Sort algorithm and binary tree knowledge where knowledge levels were about the same. This means that the programming skill of Romanian students was higher than that of their Hungarian counterparts.

At this point it should be noticed once again that Hungarian students start to learn programming later, because a big part of teachers omit this subject from the Information Technology Education of secondary schools which is however against the regulations of the National Basic Curriculum (prescribing it from the $7^{\text {th }}$ grade). 
Table 9. Percent of students answering successfully the questions grouping by Hungarian students specialized in informatics and Romanian students attending a mathematics-informatics course in the $11^{\text {th }}$ grade

\begin{tabular}{|c|c|c|c|c|c|c|}
\hline & \multicolumn{2}{|c|}{ Hungarian } & \multicolumn{2}{|c|}{ Romanian } & & \\
\hline Programming topic & $\%$ & $\begin{array}{l}\text { Std. } \\
\text { dev. }\end{array}$ & $\%$ & $\begin{array}{l}\text { Std. } \\
\text { dev. }\end{array}$ & $\begin{array}{c}\text { Value of } \\
\text { Z-test }\end{array}$ & Decision \\
\hline Flowchart & $35,2 \%$ & 0,48 & $65,0 \%$ & 0,49 & $-5,05$ & $\begin{array}{l}\text { The means } \\
\text { are not equal }\end{array}$ \\
\hline Structogram & $22,0 \%$ & 0,42 & $10,0 \%$ & 0,31 & $-1,01$ & $\begin{array}{l}\text { The means } \\
\text { are equal }\end{array}$ \\
\hline FOR cycle & $43,4 \%$ & 0,50 & $85,0 \%$ & 0,36 & $-8,55$ & $\begin{array}{l}\text { The means } \\
\text { are not equal }\end{array}$ \\
\hline Repeat-Until cycle & $19,2 \%$ & 0,40 & $32,5 \%$ & 0,47 & $-2,66$ & $\begin{array}{l}\text { The means } \\
\text { are not equal }\end{array}$ \\
\hline Do-While cycle & $26,4 \%$ & 0,44 & $52,5 \%$ & 0,51 & $-4,03$ & $\begin{array}{l}\text { The means } \\
\text { are not equal }\end{array}$ \\
\hline Parameter passing & $16,5 \%$ & 0,37 & $60,0 \%$ & 0,50 & $-4,93$ & $\begin{array}{l}\text { The means } \\
\text { are not equal }\end{array}$ \\
\hline Sort algorithm & $14,3 \%$ & 0,37 & $20,0 \%$ & 0,41 & $-1,88$ & $\begin{array}{l}\text { The means } \\
\text { are equal }\end{array}$ \\
\hline Array management & $9,9 \%$ & 0,30 & $40,0 \%$ & 0,50 & $-3,29$ & $\begin{array}{l}\text { The means } \\
\text { are not equal }\end{array}$ \\
\hline Subroutine & $42,9 \%$ & 0,50 & $70,0 \%$ & 0,46 & $-5,62$ & $\begin{array}{l}\text { The means } \\
\text { are not equal }\end{array}$ \\
\hline Stack management & $12,1 \%$ & 0,33 & $25,0 \%$ & 0,44 & $-2,26$ & $\begin{array}{l}\text { The means } \\
\text { are not equal }\end{array}$ \\
\hline binary three knowledge & $6,0 \%$ & 0,24 & $10,0 \%$ & 0,30 & $-1,32$ & $\begin{array}{l}\text { The means } \\
\text { are equal }\end{array}$ \\
\hline list knowledge & $19,2 \%$ & 0,40 & $47,5 \%$ & 0,51 & $-3,75$ & $\begin{array}{l}\text { The means } \\
\text { are not equal }\end{array}$ \\
\hline Recursion & $15,0 \%$ & 0,48 & $35,0 \%$ & 0,48 & $-2,80$ & $\begin{array}{l}\text { The means } \\
\text { are not equal }\end{array}$ \\
\hline binary search algorithm & $11,0 \%$ & 0,31 & $55,0 \%$ & 0,51 & $-4,52$ & $\begin{array}{l}\text { The means } \\
\text { are not equal }\end{array}$ \\
\hline The Eight Queens Problem & $25,0 \%$ & 0,28 & $40,0 \%$ & 0,50 & $-3,38$ & $\begin{array}{l}\text { The means } \\
\text { are not equal }\end{array}$ \\
\hline
\end{tabular}

Now let's analyse the situation in the $12^{\text {th }}$ grade too! The following table is a break-down by programming topics, showing what percent of students in the $12^{\text {th }}$ grade could answer correctly the questions put to them (Table 10.).

According to the table Romanian students attending a Mathematics-Informatics course could answer the programming questions more successfully than Hungarian students specialized in Informatics in the $12^{\text {th }}$ grade, except by Structograms, where their knowledge was the same. 
Table 10. Percent of students answering successfully the questions grouping by Hungarian students specialized in informatics and Romanian students attending a mathematics-informatics course in the $12^{\text {th }}$ grade

\begin{tabular}{|c|c|c|c|c|c|c|}
\hline & \multicolumn{2}{|c|}{ Hungarian } & \multicolumn{2}{|c|}{ Romanian } & & \\
\hline Programming topic & $\%$ & $\begin{array}{l}\text { Std. } \\
\text { dev. }\end{array}$ & $\%$ & $\begin{array}{l}\text { Std. } \\
\text { dev. }\end{array}$ & $\begin{array}{c}\text { Value of } \\
\text { Z-test }\end{array}$ & Decision \\
\hline Flowchart & $35,2 \%$ & 0,48 & $60,0 \%$ & 0,50 & $-4,52$ & $\begin{array}{l}\text { The means } \\
\text { are not equal }\end{array}$ \\
\hline Structogram & $22,0 \%$ & 0,42 & $15,0 \%$ & 0,37 & $-1,40$ & $\begin{array}{l}\text { The means } \\
\text { are equal }\end{array}$ \\
\hline FOR cycle & $43,4 \%$ & 0,50 & $65,0 \%$ & 0,48 & $-5,14$ & $\begin{array}{l}\text { The means } \\
\text { are not equal }\end{array}$ \\
\hline Repeat-Until cycle & $19,2 \%$ & 0,40 & $37,5 \%$ & 0,49 & $-3,01$ & $\begin{array}{l}\text { The means } \\
\text { are not equal }\end{array}$ \\
\hline Do-While cycle & $26,4 \%$ & 0,44 & $65,0 \%$ & 0,48 & $-5,27$ & $\begin{array}{l}\text { The means } \\
\text { are not equal }\end{array}$ \\
\hline Parameter passing & $16,5 \%$ & 0,37 & $55,0 \%$ & 0,50 & $-4,44$ & $\begin{array}{l}\text { The means } \\
\text { are not equal }\end{array}$ \\
\hline Sort algorithm & $14,3 \%$ & 0,37 & $37,5 \%$ & 0,49 & $-3,08$ & $\begin{array}{l}\text { The means } \\
\text { are not equal }\end{array}$ \\
\hline Array management & $9,9 \%$ & 0,30 & $40,0 \%$ & 0,50 & $-3,29$ & $\begin{array}{l}\text { The means } \\
\text { are not equal }\end{array}$ \\
\hline Subroutine & $42,9 \%$ & 0,50 & $78,3 \%$ & 0,42 & $-6,93$ & $\begin{array}{l}\text { The means } \\
\text { are not equal }\end{array}$ \\
\hline Stack management & $12,1 \%$ & 0,33 & $40,0 \%$ & 0,50 & $-3,28$ & $\begin{array}{l}\text { The means } \\
\text { are not equal }\end{array}$ \\
\hline binary three knowledge & $6,0 \%$ & 0,24 & $22,5 \%$ & 0,42 & $-2,24$ & $\begin{array}{l}\text { The means } \\
\text { are not equal }\end{array}$ \\
\hline list knowledge & $19,2 \%$ & 0,40 & $5,0 \%$ & 0,48 & $-5,43$ & $\begin{array}{l}\text { The means } \\
\text { are not equal }\end{array}$ \\
\hline Recursion & $15,0 \%$ & 0,48 & $40,0 \%$ & 0,49 & $-3,15$ & $\begin{array}{l}\text { The means } \\
\text { are not equal }\end{array}$ \\
\hline binary search algorithm & $11,0 \%$ & 0,31 & $50,0 \%$ & 0,51 & $-4,08$ & $\begin{array}{l}\text { The means } \\
\text { are not equal }\end{array}$ \\
\hline The Eight Queens Problem & $25,0 \%$ & 0,28 & $50,0 \%$ & 0,51 & $-4,15$ & $\begin{array}{l}\text { The means } \\
\text { are not equal }\end{array}$ \\
\hline
\end{tabular}

The programming skill of Romanian students was better than that of the Hungarian students before the final exam. Romanian students making their final exam of Information Technology and intending to go to the university or college can start their programming studies from a higher level and do not need to spend much time to acquire the basics of programming. On the contrary, Hungarian students have many problems with basic programming too, so they first have to 


$$
\text { "tmcs-kiss" — 2013/5/24 — 16:31 — page 38 — \#18 }
$$

fix this after entering university or college (generally in their first year) and they can be taught only after that on a higher level.

Therefore, Hungarian teachers should make more efforts when teaching programming in the secondary grammar schools if their students choose Information Technology as a final exam subject or when they decide to teach this part of Information Technology earlier. Also, more classes in Information Technology could be helpful too. On the other hand, university lecturers teaching programming should be aware of their students having problems with programming basics and find a way to make up for lost ground.

\section{Conclusion}

One of my starting hypothesises was that the Hungarian students specialized in Informatics would do better than their Romanian peers attending a science course.

This proved to be true in the $11^{\text {th }}$ grade except for object oriented programming a subject left out of the education in both countries.

In the $12^{\text {th }}$ grade Romanian students achieved better results in object oriented programming and SQL, and achieved the same result in programming and database management. Hungarian students performed better at theoretical knowledge, word processing and spreadsheet calculation in both grades. Here you can see the advantage of more weekly classes (3-4) taught in science courses of Information Technology Education in Romania. The students can make up for their handicap, and have same knowledge in programming and database management, and even more so in object oriented programming. Their Hungarian peers have better IT skills at the end of the secondary grammar school.

Another starting hypothesis was that as for IT skills and programming Romanian students attending a science course and a Mathematics-Informatics course would reach the same scores than the Hungarian students specialized in Information Technology.

This assumption turned out to be partly correct in the $11^{\text {th }}$ and $12^{\text {th }}$ grade. Hungarian students received higher scores in word processing, while Romanians in programming. They achieved the same scores in the other topics of Information Technology in the $11^{\text {th }}$ grade.

Romanian students attending a Mathematics-Informatics course have the same IT skills and better programing knowledge in the $12^{\text {th }}$ grade than Hungarian students specialized in Informatics. 
Here must be mentioned that while in Romania object-oriented programming has been discussed in these two courses, in Hungary students do not learn it, not even in a specialized Informatics course, though those who have to deal with programming cannot avoid getting to know this field thoroughly later on.

Now a final conclusion can be made: Romanian students of the Real Profile (i.e. the Sciences program) have the same or more practice in programming than Hungarian students specialized in Informatics, though the latters have the same or better IT skills. Unfortunately, Hungarian teachers concentrate on word processing and spreadsheet calculation and teach programming just for the students specialized in Informatics, although algorithm thinking would be important for every student before finishing secondary school.

\section{References}

[1] H. Döbert and W. Hörner, Die Schulsysteme Europas, Hohengehren, 2002.

[2] Europäische Kommission, Benchmarking Access and Use of ICT in European Schools 2006, Final Report, Bonn, Juni 2006.

[3] V. Dagienè and R. Mittermeir, Information Technologies at School, Vilnius, 2006.

[4] Schweizerische Fachstelle für Informationstechnologien im Bildungswesen (SFIB): ICT und Bildung in der Schweiz, Bern, 2004.

[5] A Kormány 243/2003. (XII.17.) Kormányrendelete a Nemzeti alaptanterv kiadásáról, bevezetéséről és alkalmazásáról.

[6] http://eacea.ec.europa.eu/education/eurydice/documents/eurybase/ eurybase_full_reports/RO_EN.pdf.

[7] Ministerul Educaţiei, Cercetării şi Inovării Cabinetul Ministrului - Legea Educaţiei Naţionale, 2009.

[8] P. Bucher and M. Wirthensohn, Test Your IT-Knowledge, Expertenbericht ICT Standardentwicklung, Zürich, 2004.

[9] P. Micheuz, Auf dem Weg zu Standards, Artikel in LOG IN, Heft 135, Berlin, 2005.

[10] G. Kiss, The Concept to Measure and Compare Students Knowledge Level in Computer Science in Germany and in Hungary, Acta Polytechnica Hungarica 5 (2008), 145-158, ISSN: 1785-8860.

[11] H. Levene, Robust tests for equality of variances, In Ingram Olkin, Harold Hotelling, et alia, Stanford University Press, 1960, 278-292.

[12] B. L. Welch, The generalization of "Student's" problem when several different population variances are involved, Biometrika 34, no. 1-2 (1947), 28-35.

[13] I. Nahalka, A változók rendszerének struktúrája, in: Bevezetés a pedagógiai kutatás módszereibe, (Falus Iván, ed.), Keraban Kiadó, Budapest, 1993. 
[14] G. Kiss, Measuring Student's Computer Science Knowledge at the End of the primary stage in Hungary $/ 9^{\text {th }}$ IEEE International Symposium on Applied Machine Intelligence and Informatics, Smolenice, Slovakia, ISBN: 978-1-4244-7428-8, pp. 19-22, 2011, IEEE Catalog Number: CFP1108E-CDR, IEEE Xplore digital library Digital Object Identifier: 10.1109/SAMI.2011.5738880; Perspective Tudományos és Kulturális Folyóirat XV. évfolyam, különszám, 2011, ISSN 1454-9921, pp. 156-164.

[15] G. Kiss, A Comparison of Informatics Skills by schooltypes in the $9-10^{\text {th }}$ grades in Hungary, International Journal of Advanced Research in computer science 2, no. 2 (2011), 279-284, ISSN: 0976-5697.

[16] G. Kiss, Measuring Computer Science knowledge at the end of secondary grammar school in Hungary, $10^{\text {th }}$ International Educational Technology Conference (IETC 2010), Istanbul, 2010, 839-842.

[17] G. Kiss, A Comparison of Programming Skills by Genders of Hungarian Grammar School Students, Symposia and Workshops on Ubiquitous, Autonomic and Trusted Computing, Xi'An, China, 2010, ISBN: 978-0-7695-4272-0, pp 24-30, IEEE Catalog Number: CFP1075H-CDR, IEEE Xplore digital library Digital Object Identifier: 10.1109/UIC-ATC.2010.83.

[18] G. Kiss, A Comparison of Informatics Skills by Genders when entering Higher Education in Hungary, $8^{\text {th }}$ IEEE International Symposium on Intelligent System and Informatics, Subotica, Serbia, 2010, ISBN: 978-1-4244-7395-3, pp 179-182, IEEE Catalog Number: CFP1084C-CDR, IEEE Xplore digital library Digital Object Identifier: 10.1109/SISY.2010.5647280.

[19] A. Korpás dr., Általános statisztika II., Budapest, 2002, 95-99.

GÁBOR KISS

ÓBUDA UNIVERSITY

DEPARTMENT OF MECHATRONICS AND VEHICLE-TECHNICS ENGINEERING

BUDAPEST

HUNGARY

E-mail: kiss.gabor@bgk.uni-obuda.hu

(Received March, 2012) 